\title{
Treatment of non-small-cell lung cancer: a perspective on the recent advances and the experience with gefitinib
}

\author{
A Onn ${ }^{*, 1}, M$ Tsuboi $^{2}$ and $\mathbf{N}$ Thatcher $^{3}$ \\ 'Department of Thoracic/Head and Neck Medical Oncology, University of Texas MD Anderson Cancer Center, Box 403, 1515 Holcombe Boulevard, \\ Houston, TX 77030-4009, USA; ${ }^{2}$ Department of Surgery, Tokyo Medical University, Tokyo, Japan; ${ }^{3}$ Department of Medical Oncology, Christie Hospital \\ NHS Trust, Manchester, UK
}

\begin{abstract}
Worldwide, non-small-cell lung cancer (NSCLC) is a leading cause of cancer-related mortality and, until screening detects early disease, treatment for the majority of patients will consist of radiation therapy, chemotherapy or combinations thereof. Modern mono and doublet chemotherapy regimens have translated into modest increases in life expectancy and improved quality of life, but at the expense of systemic and pulmonary adverse events (AEs). There is a great unmet need to provide effective therapy for advanced NSCLC that does not have the toxicity burden of conventional chemotherapy and radiotherapy. Novel drugs that inhibit a range of growth factor receptors, such as the epidermal growth factor receptor tyrosine kinase inhibitors gefitinib ('Iressa') and erlotinib ('Tarceva') or the monoclonal antibody cetuximab ('Erbitux'), have recently been evaluated. Having demonstrated antitumour activity and rapid symptom improvement in pretreated patients with advanced NSCLC, gefitinib was approved in the USA, Japan and other countries. Gefitinib is well tolerated with a low incidence of grade 3/4 AEs. Interstitial lung disease has been reported in a small number of patients receiving gefitinib, although this may be attributed to other treatments and conditions. Nevertheless, although the use of novel treatments requires vigilance for unexpected AEs such as pulmonary toxicity, in this area of high unmet clinical need, the benefits outweigh the risks in patients for whom no other proven effective treatment exists.

British Journal of Cancer (2004) 9 I (Suppl 2), SI I-SI7. doi:I0.I038/sj.bjc.6602062 www.bjcancer.com
\end{abstract} (C) 2004 Cancer Research UK

Keywords: gefitinib ('Iressa'); EGFR-TKI; NSCLC; chemotherapy

\section{NON-SMALL-CELL LUNG CANCER (NSCLC)}

Lung cancer is one of the most common malignancies in developed countries and accounts for millions of deaths worldwide. In 2000, the annual incidence of NSCLC, which comprises $80 \%$ of all lung cancer cases, was 991089 and the worldwide mortality was 882495 (Ferlay et al, 2001).

At diagnosis, patients with NSCLC can be divided into three groups, reflecting disease extent and treatment approach. The first group, patients with stage I and II disease, has the best prognosis and surgery is the treatment of choice; however, patients with inoperable disease might be considered for radiation therapy with curative intent. Careful preoperative assessment of the patient's overall pulmonary reserve is essential in considering surgery. The second group of patients (stage III) includes those with locally or regionally advanced NSCLC. These patients are often treated with combined modality treatment, that is, various combinations of chemotherapy, radiation therapy and surgery. Patients in the final group (stage IV) have advanced disease with distant metastases and can be treated with radiation therapy and/or chemotherapy.

Unfortunately, the prognosis of patients with advanced NSCLC remains poor. Systemic chemotherapy prolongs survival compared with best supportive care alone, as demonstrated in patients treated with platinum-based regimens (Non-small Cell Lung Cancer Collaborative Group, 1995). However, chemotherapeutic

\footnotetext{
*Correspondence: Dr A Onn; E-mail: amironn@mdanderson.org
}

regimens are associated with systemic (Table 1) (Schiller et al, 2002) and pulmonary adverse events (AEs). Furthermore, debilitating pulmonary and general symptoms are of central concern to patients with advanced NSCLC and lead to severe reductions in quality of life (QoL). The quest is for more effective therapeutic strategies for NSCLC that carry fewer AEs and that balance the clinical benefit gained, including symptom relief, against those AEs.

\section{ADVANCES IN THE CHEMOTHERAPY OF NSCLC}

\section{The new chemotherapy regimens}

Over the past decade, older chemotherapy regimens have been replaced by a number of new chemotherapy agents for the treatment of NSCLC, including the taxanes (paclitaxel and docetaxel), gemcitabine and vinorelbine. Vinorelbine in combination with cisplatin was the first novel combination regimen to produce a statistically significant survival advantage over a standard regimen (vindesine plus cisplatin) (Le Chevalier et al, 1994). Subsequently, in a randomised phase III trial, the Southwest Oncology Group confirmed the efficacy of vinorelbine plus cisplatin for patients with metastatic NSCLC (Wozniak et al, 1998). Several studies have been performed to compare recent doublet regimens.

A randomised phase III trial compared paclitaxel plus carboplatin with vinorelbine plus cisplatin in patients with 
Table I Common AEs associated with cancer therapy (Schiller et al, 2002)

\begin{tabular}{|c|c|c|c|}
\hline Treatment & Drug dose and regimen & Highest grade (all AEs, \%) & Most common grade $3 / 4$ AEs \\
\hline $\begin{array}{l}\text { Cisplatin and paclitaxel } \\
n=300\end{array}$ & $\begin{array}{l}\text { Paclitaxel } 135 \mathrm{mg} \mathrm{m}^{-2} \text { over } 24-\mathrm{h} \text { period } \\
\text { on day I; } \\
\text { Cisplatin } 75 \mathrm{mg} \mathrm{m}^{-2} \text { on day } 2 \text {; } \\
\text { Repeat cycle every } 21 \text { days }\end{array}$ & $\begin{array}{l}\text { Grade } 3(19) \\
\text { Grade } 4(68) \\
\text { Grade } 5(5)\end{array}$ & $\begin{array}{l}\text { Absolute neutrophil count } \\
\text { Nausea } \\
\text { Vomiting } \\
\text { Febrile neutropenia }\end{array}$ \\
\hline $\begin{array}{l}\text { Cisplatin and gemcitabine } \\
n=293\end{array}$ & $\begin{array}{l}\text { Gemcitabine } 1000 \mathrm{mg} \mathrm{m}^{-2} \text { on days I, } 8 \text {, } \\
\text { I5; } \\
\text { Cisplatin } 100 \mathrm{mg} \mathrm{m}^{-2} \text { on day I; } \\
\text { Repeat cycle every } 28 \text { days }\end{array}$ & $\begin{array}{l}\text { Grade } 3(21) \\
\text { Grade } 4(68) \\
\text { Grade } 5(4)\end{array}$ & $\begin{array}{l}\text { Absolute neutrophil count } \\
\text { Platelet count } \\
\text { Nausea } \\
\text { Vomiting }\end{array}$ \\
\hline $\begin{array}{l}\text { Cisplatin and docetaxel } \\
n=287\end{array}$ & $\begin{array}{l}\text { Docetaxel } 75 \mathrm{mg} \mathrm{m}^{-2} \text { on day I; } \\
\text { Cisplatin } 75 \mathrm{mg} \mathrm{m}^{-2} \text { on day I; } \\
\text { Repeat cycle every } 21 \text { days }\end{array}$ & $\begin{array}{l}\text { Grade } 3(23) \\
\text { Grade } 4(61) \\
\text { Grade } 5(6)\end{array}$ & $\begin{array}{l}\text { Absolute neutrophil count } \\
\text { Nausea } \\
\text { Vomiting } \\
\text { Weakness }\end{array}$ \\
\hline $\begin{array}{l}\text { Carboplatin and paclitaxel } \\
n=293\end{array}$ & $\begin{array}{l}\text { Paclitaxel } 225 \mathrm{mg} \mathrm{m}^{-2} \text { over } 3-\mathrm{h} \text { period } \\
\text { on day I; } \\
\text { Carboplatin, AUC } 6.0 \mathrm{mg} \mathrm{ml}^{-1} \mathrm{~min}^{-1} \text { on } \\
\text { day I; } \\
\text { Repeat cycle every } 21 \text { days }\end{array}$ & $\begin{array}{l}\text { Grade } 3(28) \\
\text { Grade } 4(53) \\
\text { Grade } 5 \text { (4) }\end{array}$ & $\begin{array}{l}\text { Absolute neutrophil count } \\
\text { Weakness } \\
\text { Platelet count } \\
\text { Anaemia }\end{array}$ \\
\hline
\end{tabular}

$\mathrm{AE}=$ adverse events. Adapted with permission from Schiller et al (2002). Copyright (C) 2002 Massachusetts Medical Society. All rights reserved.

metastatic NSCLC (Kelly et al, 2001). No difference in efficacy was observed between the two treatment arms, with objective response rates of 25 and $28 \%$, median survival times of 8 months in both arms and 1-year survival rates of 38 and $36 \%$, respectively. Less toxicity was observed with the paclitaxel plus carboplatin regimen.

The Eastern Cooperative Oncology Group (ECOG) reported results from a randomised trial in patients with advanced NSCLC that compared the efficacy of a reference regimen of cisplatin and paclitaxel with three experimental regimens: cisplatin and gemcitabine, cisplatin and docetaxel, and carboplatin and paclitaxel (Schiller et al, 2002). The response rate and survival did not differ significantly between patients assigned to receive cisplatin and paclitaxel and those assigned to receive any of the three experimental regimens (Figure 1) (Schiller et al, 2002). However, there was a suggestion that time to progression was more favourable with the gemcitabine combination. Treatment with cisplatin and gemcitabine was more likely to cause grade 3,4 or 5 renal toxicity, while the combination of carboplatin and paclitaxel was considered, comparatively, to be the most tolerable.

Results from a randomised phase III trial of docetaxel plus platinum regimens $v s$ vinorelbine plus cisplatin for first-line therapy of advanced NSCLC were recently reported (Fossella et al, 2003). A more favourable overall response and survival rate was observed in patients treated with a docetaxel regimen than the vinorelbine combination: overall response rates were 31.6 and $24.5 \%$ for patients treated with docetaxel and vinorelbine, respectively $(P=0.029)$; median survival was 11.3 months and 10.1 months, respectively. Compared with vinorelbine plus cisplatin, the docetaxel regimen was better tolerated and consistently improved QoL.

Three-drug combinations might also be an option for treatment of NSCLC. However, at least two randomised trials found no benefit for chemotherapy triplets over doublets (Pirker, 2002) and, as toxicity is likely to be high, there is no justification for increasing the number of chemotherapy drugs in a treatment regimen beyond two unless the benefit:risk ratio has been demonstrated to be favourable.

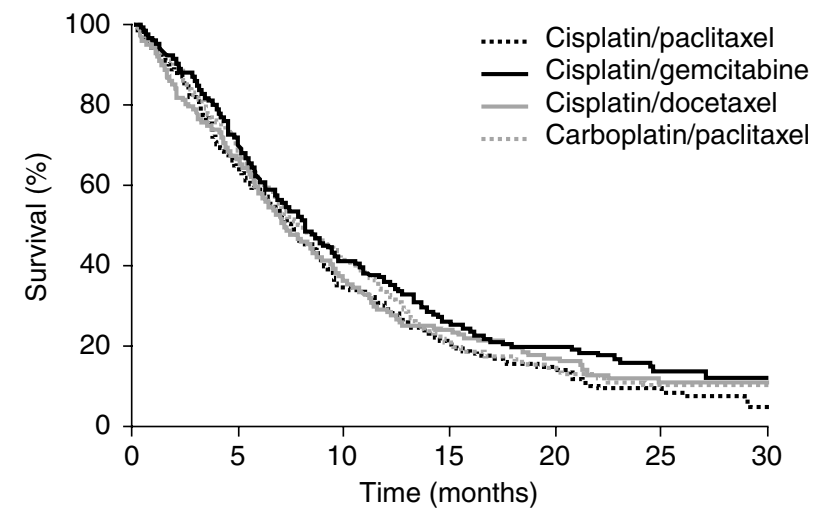

Figure I Survival of patients with stage IV NSCLC receiving four different platinum-based combination chemotherapy regimens (Schiller et al, 2002). Reprinted with permission from: Schiller et al (2002). Copyright (C) 2002 Massachusetts Medical Society. All rights reserved.

\section{Cisplatin or carboplatin regimens?}

A number of first-line chemotherapy options are advocated in treatment guidelines and/or by various clinical investigators for the treatment of patients with advanced NSCLC. Platinum-based chemotherapy has clearly demonstrated efficacy in patients with advanced NSCLC and there is increasing interest in the use of nonplatinum chemotherapy regimens. Regimens such as cisplatin or carboplatin combined with paclitaxel, vinorelbine, gemcitabine, docetaxel or irinotecan are among the platinum-based combinations currently used in clinical practice. The particular combinations employed may vary between institutions and geographical regions and, although a number of studies have compared cisplatin- with carboplatin-based regimens, no definitive evidence suggests either agent to be better. An early ECOG study compared three cisplatin-based regimens with single-agent carboplatin, and the results demonstrated that carboplatin-treated patients had better overall survival and less toxicity than cisplatin-based 
regimens (Bonomi et al, 1989). Likewise, a randomised phase III study that compared cisplatin and carboplatin in combination with vindesine and mitomycin $\mathrm{C}$ indicated a survival advantage for the carboplatin regimen (Jelic et al, 2001). In contrast, a paclitaxel/ cisplatin regimen was better than a carboplatin regimen (Rosell et al, 2002) and no significant differences in survival were apparent in a further trial comparing cisplatin and etoposide with carboplatin and etoposide by the European Organisation for Research and Treatment of Cancer (Klastersky et al, 1990).

\section{Chemotherapy in the elderly and poor performance status (PS) patients}

Approximately one-third of all patients with NSCLC are $>70$ years of age and, although these patients are likely to have an increased risk of comorbid conditions and impaired organ function, most studies have suggested that age alone should not be a factor in the decision to treat patients with chemotherapy. A retrospective study of patients treated for advanced NSCLC found no major differences between patients older or younger than 65 years of age (Giovanazzi-Bannon et al, 1994), and an analysis of age as a risk factor in chemotherapy trials found that the response, toxicity and survival rates of elderly patients were similar to those of younger patients (Langer et al, 2002).

Two important phase III randomised studies of chemotherapy in the elderly have been reported (Fossella et al, 2000; Gridelli, 2001). The Elderly Lung Cancer Vinorelbine Italian Study group performed a multicentre, randomised trial of single-agent vinorelbine as a first-line agent in elderly patients with advanced NSCLC. Results demonstrated that the addition of vinorelbine to best supportive care significantly prolonged survival in this group of patients (Gridelli, 2001). The median survival for best supportive care plus vinorelbine was 28 weeks compared with 21 weeks for best supportive care alone. This benefit was achieved at the cost of some drug-related toxicity, reflected in lower scores on QoL subscales that were directly related to drug toxicity (e.g. nausea and constipation). However, patients who received vinorelbine scored better than control patients on overall health status and QoL, and suffered less from the lung cancer symptoms of dyspnoea, cough and haemoptysis.

More recently, the Multicentre Italian Lung cancer in the Elderly Study randomised elderly patients with advanced NSCLC to vinorelbine, gemcitabine or vinorelbine plus gemcitabine (Gridelli et al, 2003). Results demonstrated that the combination of gemcitabine plus vinorelbine in this patient population does not improve survival or QoL compared with single-agent chemotherapy with vinorelbine or gemcitabine. The combination treatment was more toxic than the agents administered alone.

Overall, the studies in elderly patients with NSCLC demonstrate that chemotherapy regimens can lead to an improvement in survival with a better QoL. However, careful attention should be paid to the toxicity of treatment regimens and the coexisting comorbidities in this patient population.

For PS 2 patients, the benefit of chemotherapy remains to be conclusively demonstrated. A survival advantage in this group of patients was demonstrated for carboplatin and paclitaxel compared with single-agent paclitaxel in a phase III randomised trial (Lilenbaum et al, 2002). The median survival was 4.7 months for the combination of paclitaxel and carboplatin and 2.4 months for paclitaxel alone. At 1 year, survival rates were $18 \%$ for the combination compared with $10 \%$ for paclitaxel alone. The outcome of patients with PS 2 was also reported in an ECOG study that compared paclitaxel and cisplatin with three newer chemotherapy doublets in the treatment of patients with advanced NSCLC (Sweeney et al, 2001). In this study, patients with PS 2 experienced a large number of AEs and overall poor survival. The overall median survival of all 68 patients who enrolled was 4.1 months. A comparison with patients with a PS of $0-1$ suggests that the shorter survival in patients with a PS of 2 was related to tumour progression rather than treatment. Alternative strategies specifically tailored for this group of patients need to be further explored.

\section{Advances in second-line chemotherapy}

With increased use of chemotherapy, the number of patients seeking second-line therapy after relapse following first-line treatment has increased. Available treatments for second-line therapy are limited and patients with tumour progression at this stage generally have very poor prognoses.

The TAX 320 NSCLC Study Group performed a phase III trial in which patients with advanced NSCLC who had previously failed platinum-containing chemotherapy were randomised to 75 or $100 \mathrm{mg} \mathrm{m}^{-2}$ docetaxel or a reference regimen of vinorelbine or ifosfamide (Fossella et al, 2000). Overall response rates were 6.7 and $10.8 \%$ with 75 and $100 \mathrm{mg} \mathrm{m}^{-2}$ docetaxel, respectively, each significantly higher than the $0.8 \%$ response with vinorelbine or ifosfamide. Overall survival did not differ significantly between the three groups, although the 1-year survival was significantly greater with $75 \mathrm{mg} \mathrm{m}^{-2}$ docetaxel than the control treatment.

In another trial, patients with NSCLC were randomised to either docetaxel or best supportive care (Shepherd et al, 2000). Docetaxel was initially administered at $100 \mathrm{mg} \mathrm{m}^{-2}$ every 21 days, but was later reduced to $75 \mathrm{mg} \mathrm{m}^{-2}$ every 21 days due to an unacceptable toxic death rate at the higher dose. Despite low overall response rates, patients treated with docetaxel survived longer. The overall response rate for docetaxel, based on 84 patients with measurable lesions, was $7.1 \%$. The median survival was 7.0 months for patients receiving docetaxel compared with 4.6 months for patients receiving best supportive care. Quality-of-life analysis demonstrated less worsening of PS and less use of tumour-related medications for docetaxel-treated patients.

Although docetaxel appears to demonstrate the most consistent efficacy as a second-line treatment and has recently been approved for first-line treatment when combined with cisplatin, it is associated with a high incidence of haematological toxicity. An alternative chemotherapy treatment option is the experimental agent pemetrexed, a new antifolate. In a phase III study in previously treated patients with recurrent NSCLC, pemetrexed (used with vitamin supplements) had a more favourable haematological toxicity profile when compared with docetaxel (Hanna et al, 2003); patients experienced less severe neutropenia, fewer hospitalisations and less need for granulocyte colony-stimulating factor/granulocyte-macrophage colony-stimulating factor support. Pemetrexed therapy, while less toxic, was still associated with haematological toxicity, hospital admissions and haematological growth factor support, and did not improve overall outcome compared with docetaxel; hence, there is still an unmet need for efficacious, well-tolerated treatment options.

\section{The therapeutic ratios of chemotherapy regimens}

In making decisions for treatment regimens, it is necessary to consider the overall therapeutic index, that is, not just the response rate or survival but also the toxicity of treatment and the subsequent outcomes. Cytotoxic chemotherapy regimens are often associated with significant toxicity, which has a detrimental effect on a patient's QoL. Furthermore, such toxicity may result in a patient opting not to receive chemotherapy. Indeed, in a recent study assessing the treatment preferences of patients with lung cancer, only $22 \%$ said they would choose chemotherapy over best supportive care for a 3-month improvement in survival, while the majority (68\%) would choose chemotherapy if it substantially reduced symptoms without an improvement in survival (Silvestri et al, 1998). 


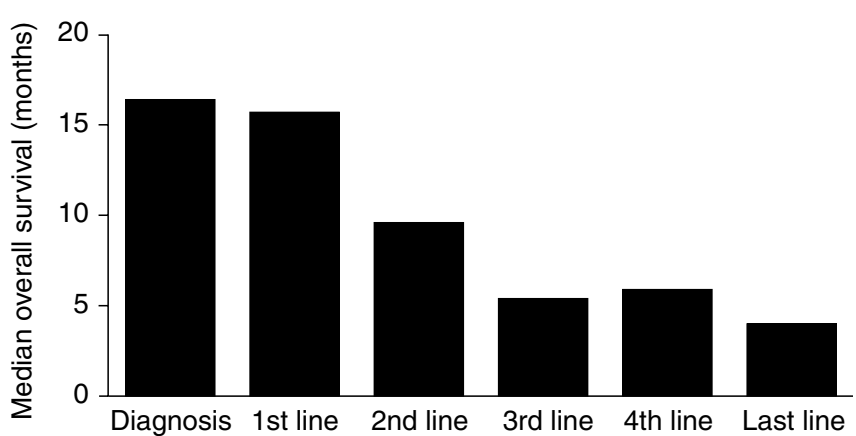

Figure 2 Median overall survival time for each line of treatment (Massarelli et al, 2003). Reprinted from: Massarelli et al (2003). Copyright (2003), with permission from Elsevier.

\section{The unmet need for new paradigms of treatment for NSCLC}

Chemotherapy treatment and supportive care to manage some unwanted side effects has progressed in the past decade. Indeed, the new doublet treatment regimens provide advantages for patients and some improvement in survival and QoL over the older chemotherapy regimens. Despite these advances in treatment, improvements in the survival of patients with NSCLC in recent years have been modest. For patients with advanced disease with good enough PS to tolerate and thus receive third- or fourthline chemotherapy, a retrospective analysis reported the median overall survival from the start of the last treatment as 4 months (Figure 2) (Massarelli et al, 2003).

Clinical data over the past decade show that there is unlikely to be further significant improvement in outcome using conventional treatment and, as there are few options for patients who have relapsed following chemotherapy, there is an unmet need for the treatment of NSCLC.

The trend of not receiving any chemotherapy with curative intent is especially common among elderly patients. In a study of the management of 6300 Medicare patients aged $>65$ years who were diagnosed with stage IV NSCLC, the authors found that only $21.5 \%$ received chemotherapy for metastatic disease (Earle et al, 2000). They noted that despite the fact that all patients had the same health insurance cover, the use of chemotherapy was far from consistent for all beneficiaries. In this cohort, younger patients and those with few comorbid conditions were more likely to receive chemotherapy but several nonmedical factors, such as nonblack race, higher socioeconomic status, treatment in a teaching hospital and living in certain urban areas, also significantly increased a patient's likelihood of receiving chemotherapy (Earle et al, 2000). Scepticism towards treatment was also common among Canadian physicians; only $20 \%$ thought that treating advanced NSCLC with chemotherapy was worthwhile (Raby et al, 1995). In the UK, only $11 \%$ of clinicians recommended chemotherapy for appropriate elderly patients, whereas $26 \%$ advised therapy if the patient was $<50$ years of age (Crook et al, 1997). New modalities of therapy may improve these numbers and increase the percentage of treated patients.

\section{GEFITINIB: A NOVEL TARGETED THERAPY FOR NSCLC}

\section{Epidermal growth factor receptor (EGFR)}

The EGFR is expressed in a wide range of solid tumours and is associated with a poor prognosis in several malignancies. Indeed, evidence for a role for the EGFR in the inhibition and pathogenesis of various cancers has led to the development of agents that target this receptor. Those most advanced in development are the EGFR tyrosine kinase inhibitors (EGFR-TKIs) gefitinib ('Iressa') and erlotinib ('Tarceva'), and the monoclonal antibody cetuximab ('Erbitux').

\section{Clinical trials with gefitinib}

Gefitinib is the EGFR-TKI with the most extensive clinical experience, particularly in NSCLC. Based on data from two pivotal phase II trials, IDEAL ('Iressa' Dose Evaluation in Advanced Lung cancer) 1 and 2 (Fukuoka et al, 2003a; Kris et al, 2003), gefitinib $250 \mathrm{mg}$ once daily was recently approved for use in patients with previously treated advanced NSCLC in Japan, the USA and other countries. Patients in both studies had been pretreated and, while all patients had a poor prognosis, patients in IDEAL 1 had a better prognosis than those in IDEAL 2. In IDEAL 1, patients had received one or two prior chemotherapy regimens (at least one platinum based), whereas in IDEAL 2 all patients had received two or more prior chemotherapy regimens (which must have included platinum and docetaxel). All had received their last dose of chemotherapy within the previous 90 days and had recurrent disease or were unable to tolerate further chemotherapy, usually as a result of chemotherapy-associated neuropathy. Furthermore, all patients in IDEAL 2 and $66.7 \%$ of patients in IDEAL 1 were symptomatic at trial entry. At the recommended dose of $250 \mathrm{mg} \mathrm{day}^{-1}$, the objective tumour response rates were 18.4 and $11.8 \%$ in IDEAL 1 and 2, respectively. Objective responses observed in patients with large or bulky measurable tumours and in patients with extensive, nonmeasurable disease were also durable; median durations of response at $250 \mathrm{mg} \mathrm{day}^{-1}$ were 13.0 and 7.0 months in IDEAL 1 and 2, respectively (Fukuoka et al, 2003b). Survival data were encouraging and disease control rates (response plus stable disease) showed that almost half of the patients treated with gefitinib in both trials benefited from treatment: median survival rates at $250 \mathrm{mg} \mathrm{day}^{-1}$ were 7.6 and 6.5 months in IDEAL 1 and 2, respectively; disease control rates at $250 \mathrm{mg} \mathrm{day}^{-1}$ were 54.4 and $42.2 \%$, respectively. In both IDEAL 1 and 2, disease-related symptoms improved significantly for many patients. At the recommended dose of $250 \mathrm{mg}^{-1 a y}{ }^{-1}$ gefitinib, 40.3 and $43.1 \%$ of symptomatic patients in IDEAL 1 and 2, respectively, experienced improvement in their disease-related symptoms that lasted for at least 1 month. Symptom relief was also rapid: the median time to onset of improvement was 8 days in IDEAL 1 and 10 days in IDEAL 2 (the times of the first postbaseline assessment for each study).

Results of preliminary studies suggested that first-line combination therapy with gefitinib and platinum-based chemotherapy is feasible and support further investigation of these combinations in NSCLC. However, in the phase III combination trials INTACT ('Iressa' NSCLC Trial Assessing Combination Treatment) 1 and 2, which involved $>2100$ chemonaive patients with advanced NSCLC, gefitinib provided no additional survival benefit in the first-line setting. Nevertheless, results confirmed the safety role of gefitinib in a placebo-controlled setting (Johnson et al, 2002): there was no worsening of chemotherapy-associated toxicities and the observed side effects of skin rash, acne and diarrhoea were as predicted from the IDEAL trials. In light of monotherapy activity, the reasons for the lack of increased activity in combination therapy are yet to be determined, although current studies are trying to analyse retrospectively the biological profile of responders $v s$ nonresponders.

\section{ADVANCES IN THE TREATMENT OF NSCLC IN JAPAN}

\section{The Japanese incidence rates of NSCLC}

Lung cancer remains the leading cause of cancer-related death in Japan despite efforts to promote early detection and surgery. 
Statistics from the Japanese Ministry of Health, Labour and Welfare show approximately 55000 deaths from lung cancer yearly in Japan and predict an $80 \%$ increase in incidence over the next 15 years.

\section{Types of treatment for lung cancer}

Globally, surgery is the treatment of choice for patients with stage I and II NSCLC and for patients with advanced disease, the principal forms of treatment are radiation therapy, chemotherapy, surgery and a combination of these options. In Japan, in contrast to the rest of the world, surgery is the primary treatment option offered to those with advanced disease. UFT, a combination of tegafur and uracil, is also widely available in Japan, where researchers have demonstrated the utility of this agent as adjuvant therapy after surgical resection, whether alone or in combination with cisplatin and vindesine (Langer, 1999). Further research is required to determine whether this agent will have a role in treatment of NSCLC outside Japan.

\section{Preferred chemotherapy regimens in Japan}

In Japan, platinum-based regimens are the preferred standard chemotherapy for NSCLC at present. However, chemotherapy for NSCLC in Japan is controversial because the differences in the efficacies of combination chemotherapies, including new agents such as irinotecan, paclitaxel and vinorelbine, have not been recognised in randomised controlled trials. The Four-Arm Cooperative Study for advanced NSCLC is an ongoing postmarketing clinical trial in Japan that was designed to compare three platinum-based combination regimens (carboplatin plus paclitaxel, cisplatin plus gemcitabine and cisplatin plus vinorelbine) with cisplatin plus irinotecan as the reference arm (Ohe et al, 2003) (Figure 3). To date, similar response rates have been observed in all four treatment arms. Toxicity was also a feature of each treatment arm: thrombocytopenia and diarrhoea were very common. There is no 'Gold Standard' therapy for the treatment of NSCLC in Japan and the development of new agents, particularly molecular-target-based drugs such as gefitinib, is necessary to further improve therapeutic results in lung cancer.

Approximately 37000 patients have received gefitinib in Japan and, up to January 2003, 84 patients had received gefitinib in clinical practice at the Tokyo Medical University (Table 2). Overall, the partial response rate was $15.5 \%$ and stable disease rate was $45.2 \%$. In this difficult-to-treat patient population, the median time to disease progression was 4 months. Gefitinib was generally well tolerated: grade 3/4 AEs included one pulmonary, one skin and one hepatic event. Individual patients also experienced improvement in QoL. For example, a patient with NSCLC liver metastases was able to perform activities not previously possible following the administration of gefitinib. Furthermore, an improvement in liver function was observed.

The incidence of interstitial lung disease (ILD) in patients treated with gefitinib in Japan was recently reported as being $2 \%$ (Forsythe and Faulkner, 2003). However, the reported incidence of ILD in $>80000$ patients who have received gefitinib worldwide is approximately $1 \%$, and it is $0.3 \%$ in a worldwide compassionateuse programme in $>38000$ patients, in which investigators must submit safety data (Forsythe and Faulkner, 2003). Although vigilance for pulmonary toxicity is mandatory, in this area of high unmet clinical need, the benefits of gefitinib outweigh the risks in patients for whom no other proven effective treatment option exists.

Table 2 Tokyo Medical University experiences with gefitinib: patient demography

\begin{tabular}{|c|c|}
\hline & Gefitinib, $250 \mathrm{mg} \mathrm{day}^{-1}$ \\
\hline No. patients treated & 84 \\
\hline Mean (range) age, years & $65.5(35-87)$ \\
\hline Male: female, $n$ & $44: 40$ \\
\hline \multicolumn{2}{|l|}{ Performance status, $n$} \\
\hline $0-1$ & 75 \\
\hline 2 & 9 \\
\hline \multicolumn{2}{|l|}{ Tumour histology, n } \\
\hline Adenocarcinoma & 68 \\
\hline Nonadenocarcinoma & 16 \\
\hline \multicolumn{2}{|l|}{ Disease stage } \\
\hline IV & 32 \\
\hline III a/b & $10 / 23$ \\
\hline$\| \mathrm{a} / \mathrm{b}$ & $1 / 0$ \\
\hline Postoperative & 18 \\
\hline \multicolumn{2}{|l|}{ Previous cancer treatment, $n$} \\
\hline 0 prior regimens & । \\
\hline I prior regimen & 35 \\
\hline$\geqslant 2$ prior regimens & 48 \\
\hline
\end{tabular}

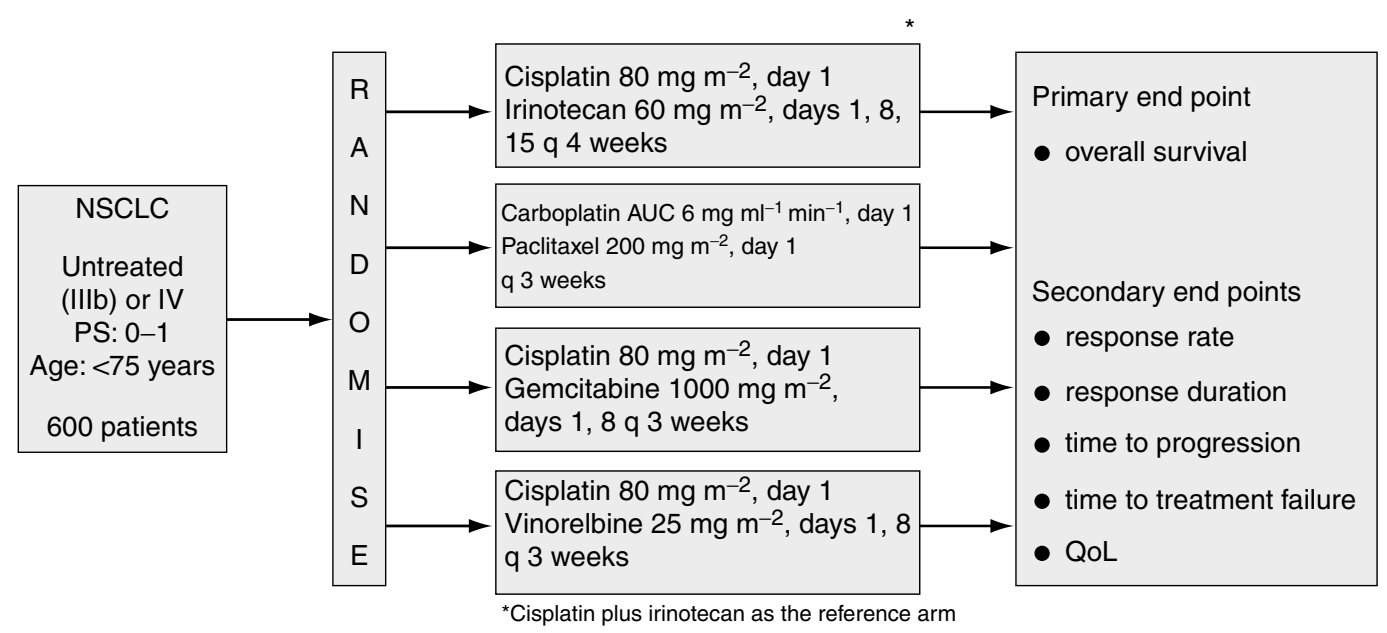

Figure 3 Four-Arm Cooperative Study for advanced NSCLC in Japan: trial design. 
The antitumour activity of gefitinib, together with its favourable tolerability profile and oral bioavailability in patients with advanced NSCLC who have previously received treatment with cytotoxic chemotherapy, has led to the development of a programme of clinical trials to define the further potential of gefitinib in NSCLC. In Japan, planned or ongoing trials will assess the effect of gefitinib as monotherapy and in combination with radiotherapy and chemotherapy. A translational research project is also ongoing. The outcome of these and other trials may lead to opportunities to change the current treatment strategies for NSCLC.

\section{Future therapies for NSCLC}

Despite recent advances in treatment of NSCLC with chemotherapeutic regimens, the prognosis for this patient population remains poor. Molecular targets have recently been identified as a result of advances in molecular biology; subsequently, many novel categories of anticancer drugs have been developed. One example of this approach is a better understanding of growth signalling pathways. The EGF pathway contributes to the malignant potential of NSCLC and several compounds have been developed to selectively block this pathway, for example, the EGFR-TKIs gefitinib and erlotinib and the monoclonal antibody cetuximab. Most advanced in research are the TKIs, which have demonstrated similar efficacy and safety profiles. Gefitinib is the agent with the most extensive clinical experience and recently it was approved for use as a monotherapy in patients with previously treated advanced NSCLC in Japan, the USA and other countries.
Thus, gefitinib is already providing responses and disease stabilisation in patients with NSCLC and no other treatment options.

Further research is required to better understand the role of the EGFR in NSCLC since its significance in individual tumours has not yet been fully identified. Determining the specific cases in which the EGFR plays a pivotal function in carcinogenesis may help to recognise those patients who may benefit from therapy with EGFR inhibitors. Several research directions address this issue: animal studies have demonstrated that EGFR-TKIs have a better antitumour effect when both the tumour and the tumourassociated endothelial cells express the target receptor (Baker et al, 2002); and human NSCLC tumour analyses have shown that coexpression of both the EGFR and HER2 affected survival more than either of the receptors alone (Brabender et al, 2001; Onn et al, 2004). In addition to studies of the role of the EGFR in NSCLC, investigation of different combination therapies is still required and the sequencing of biological compounds with conventional chemotherapy or radiotherapy may provide evidence for directing future studies. Indeed, the molecular diversity of tumours may ultimately necessitate a combination of biological agents to maximise therapeutic effects.

\section{ACKNOWLEDGEMENTS}

'Iressa' is a trademark of the AstraZeneca group of companies; 'Tarceva' is a trademark of OSI Pharmaceuticals Inc; 'Erbitux' is a trademark of ImClone Systems Inc.

\section{REFERENCES}

Baker CH, Kedar D, McCarty MF, Tsan R, Weber KL, Bucana CD, Fidler IJ (2002) Blockade of epidermal growth factor receptor signaling on tumor cells and tumor-associated endothelial cells for therapy of human carcinomas. Am J Pathol 161: 929-938

Bonomi PD, Finkelstein DM, Ruckdeschel JC, Blum RH, Green MD, Mason B, Hahn R, Tormey DC, Harris J, Comis R, Glick J (1989) Combination chemotherapy $v s$ single agents followed by combination chemotherapy in stage IV non-small-cell lung cancer: a study of the Eastern Cooperative Oncology Group. J Clin Oncol 7: $1602-1613$

Brabender J, Danenberg KD, Metzger R, Schneider PM, Park J, Salonga D, Holscher AH, Danenberg PV (2001) Epidermal growth factor receptor and HER2-neu mRNA expression in non-small cell lung cancer is correlated with survival. Clin Cancer Res 7: 1850-1855

Crook A, Duffy A, Girling DJ, Souhami RL, Parmar MK (1997) Survey on the treatment of non-small cell lung cancer (NSCLC) in England and Wales. Eur Respir J 10: $1552-1558$

Earle CC, Venditti LN, Neumann PJ, Gelber RD, Weinstein MC, Potosky AL, Weeks JC (2000) Who gets chemotherapy for metastatic lung cancer? Chest 117: 1239-1246

Ferlay J, Bray F, Pisani P, Parkin DM (2001) GLOBOCAN 2000: Cancer incidence, mortality and prevalence worldwide, version 1.0. IARC. CancerBase No. 5. Available at http://www-dep.iarc.fr/globocan/ globocan.html

Forsythe B, Faulkner K (2003) Clinical experience with gefitinib ('Iressa', ZD1839): an overview of safety and tolerability. Lung Cancer 41(Suppl 2): S70 - S71 (abstr. O-240)

Fossella F, Pereira JR, von Pawel J, Pluzanska A, Gorbounova V, Kaukel E, Mattson KV, Ramlau R, Szczesna A, Fidias P, Millward M, Belani CP (2003) Randomized, multinational, phase III study of docetaxel plus platinum combinations $v s$ vinorelbine plus cisplatin for advanced non-small-cell lung cancer: the TAX 326 study group. J Clin Oncol 21: $3016-3024$

Fossella FV, DeVore R, Kerr RN, Crawford J, Natale RR, Dunphy F, Kalman L, Miller V, Lee JS, Moore M, Gandara D, Karp D, Vokes E, Kris M, Kim Y, Gamza F, Hammershaimb L, The TAX 320 Non-Small Cell Lung Cancer Study Group (2000) Randomized phase III trial of docetaxel vs vinorelbine or ifosfamide in patients with advanced non-small-cell lung

cancer previously treated with platinum-containing chemotherapy regimens. J Clin Oncol 18: 2354-2362

Fukuoka M, Kris M, Giaccone G, Lynch T, Nakagawa K, Kelly K, Wolf M, McPartlane A, Kay A, Fandi A (2003b) Phase II trials of gefitinib ('Iressa', ZD1839): rapid and durable objective responses in patients with advanced non-small-cell lung cancer (IDEAL 1 and IDEAL 2). Lung Cancer 41(Suppl 2): S247 - S248 (abstr. P-615)

Fukuoka M, Yano S, Giaccone G, Tamura T, Nakagawa K, Douillard J-Y, Nishiwaki Y, Vansteenkiste J, Kudoh S, Rischin D, Eek R, Horai T, Noda K, Takata I, Smit E, Averbuch S, Macleod A, Feyereislova A, Dong R-P, Baselga J (2003a) Multi-institutional randomized phase II trial of gefitinib for previously treated patients with advanced non-small-cell lung cancer. J Clin Oncol 21: 2237-2246

Giovanazzi-Bannon S, Rademaker A, Lai G, Benson III AB (1994) Treatment tolerance of elderly cancer patients entered onto phase II clinical trials: an Illinois Cancer Center study. J Clin Oncol 12: 2447 - 2452

Gridelli C (2001) The ELVIS trial: a phase III study of single-agent vinorelbine as first-line treatment in elderly patients with advanced nonsmall cell lung cancer. Oncologist 6(Suppl 1): 4-7

Gridelli C, Perrone F, Gallo C, Cigolari S, Rossi A, Piantedosi F, Barbera S, Ferrau F, Piazza E, Rosetti F, Clerici M, Bertetto O, Robbiati SF, Frontini L, Sacco C, Castiglione F, Favaretto A, Novello S, Migliorino MR, Gasparini G, Galetta D, Iaffaioli RV, Gebbia V, MILES Investigators (2003) Chemotherapy for elderly patients with advanced non-small-cell lung cancer: the Multicenter Italian Lung Cancer in the Elderly Study (MILES) phase III randomized trial. J Natl Cancer Inst 95: 362 - 372

Hanna NH, Shepherd FA, Rosell R, Pereira JR, De Marinis F, Fossella F, Kayitalire L, Paul S, Einhorn LH, Bunn PA (2003) A phase III study of pemetrexed $v s$ docetaxel in patients with recurrent non-small cell lung cancer (NSCLC) who were previously treated with chemotherapy. Proc Am Soc Clin Oncol 22: 622 (abstr. 2503)

Jelic S, Mitrovic L, Radosavljevic D, Elezar E, Babovic N, Kovcin V, Tomasevic Z, Kovacevic S, Gavrilovic D, Radulovic S (2001) Survival advantage for carboplatin substituting cisplatin in combination with vindesine and mitomycin C for stage IIIB and IV squamous-cell bronchogenic carcinoma: a randomized phase III study. Lung Cancer 34: $1-13$ 
Johnson DH, Herbst R, Giaccone G, Schiller J, Natale RB, Miller V, Wolf M, Helton A, Averbuch S, Grous J (2002) ZD1839 ('Iressa') in combination with paclitaxel \& carboplatin in chemotherapy-naive patients with advanced non-small-cell lung cancer (NSCLC): Results from a phase III clinical trial (INTACT 2). Ann Oncol 13(Suppl 5): 127 (abstr. 4680)

Kelly K, Crowley J, Bunn Jr PA, Presant CA, Grevstad PK, Moinpour CM, Ramsey SD, Wozniak AJ, Weiss GR, Moore DF, Israel VK, Livingston RB, Gandara DR (2001) Randomized phase III trial of paclitaxel plus carboplatin $v s$ vinorelbine plus cisplatin in the treatment of patients with advanced non-small-cell lung cancer: a Southwest Oncology Group trial. J Clin Oncol 19: 3210 - 3218

Klastersky J, Sculier JP, Lacroix H, Dabouis G, Bureau G, Libert P, Richez M, Ravez P, Vandermoten G, Thiriaux J, Cordier R, Finet C, Berchier MC, Sergysels R, Mommen P, Paesmans M, for the European Organization for Research and Treatment of Cancer Lung Cancer Working Party (1990) A randomized study comparing cisplatin or carboplatin with etoposide in patients with advanced non-small-cell lung cancer: European Organization for Research and Treatment of Cancer Protocol 07861. J Clin Oncol 8: $1556-1562$

Kris MG, Natale RB, Herbst RS, Lynch Jr TJ, Prager D, Belani CP, Schiller JH, Kelly K, Spiridonidis H, Sandler A, Albain KS, Cella D, Wolf MK, Averbuch SD, Ochs JJ, Kay AC (2003) Efficacy of gefitinib, an inhibitor of the epidermal growth factor receptor tyrosine kinase, in symptomatic patients with non-small cell lung cancer. A randomized trial. JAMA 290: $2149-2158$

Langer CJ (1999) The role of tegafur/uracil in pulmonary malignancy. Drugs 58(Suppl 3): $71-75$

Langer CJ, Manola J, Bernardo P, Kugler JW, Bonomi P, Cella D, Johnson DH (2002) Cisplatin-based therapy for elderly patients with advanced non-small-cell lung cancer: implications of Eastern Cooperative Oncology Group 5592, a randomized trial. J Natl Cancer Inst 94: 173-181

Le Chevalier T, Brisgand D, Douillard J-Y, Pujol J-L, Alberola V, Monnier A, Riviere A, Lianes P, Chomy P, Cigolari S, Gottfried M, Ruffie P, Panizo A, Gaspard M-H, Ravaioli A, Besenval M, Besson F, Martinez A, Berthaud $\mathrm{P}$, Tursz T (1994) Randomized study of vinorelbine and cisplatin $v s$ vindesine and cisplatin $v s$ vinorelbine alone in advanced non-small-cell lung cancer: results of a European multicenter trial including 612 patients. J Clin Oncol 12: 360-367

Lilenbaum RC, Herndon J, List M, Desch C, Watson D, Holland J, Weeks JC, Green MR (2002) Single-agent (SA) vs combination chemotherapy (CC) in advanced non-small cell lung cancer (NSCLC): a CALGB randomized trial of efficacy, quality of life (QOL), and cost-effectiveness. Poster presented at ASCO, Orlando, FL, USA, May 18-21, Poster no. 2

Massarelli E, Andre F, Liu DD, Lee JJ, Wolf M, Fandi A, Ochs J, Le Chevalier T, Fossella F, Herbst RS (2003) A retrospective analysis of the outcome of patients who have received two prior chemotherapy regimens including platinum and docetaxel for recurrent non-small-cell lung cancer. Lung Cancer 39: 55-61

Non-small Cell Lung Cancer Collaborative Group (1995) Chemotherapy in non-small cell lung cancer: a meta-analysis using updated data on individual patients from 52 randomised clinical trials. BMJ 311: 899-909

Ohe Y, Saijo N, Ohashi Y, Nishiwaki Y, Nakagawa K, Tamura T, Negoro S, Kubota K, Ariyoshi Y, Fukuoka M (2003) Preliminary results of the FourArm Cooperative Study (FACS) for advanced non-small cell lung cancer (NSCLC) in Japan. Proc Am Soc Clin Oncol 22: 624 (abstr. 2509)

Onn A, Correa AM, Gilcrease M, Isobe T, Massarelli E, Bucana CD, O'Reilly MS, Hong WK, Fidler IJ, Putnam JB, Herbst RS (2004) Synchronous overexpression of epidermal growth factor receptor and HER2-neu protein is a predictor of poor outcome in patients with stage I non-small cell lung cancer. Clin Cancer Res 10: 136-143

Pirker R (2002) Two- $v s$ three-drug combinations in the chemotherapy of advanced non-small-cell lung cancer. Lung Cancer 38: S53-S55

Raby B, Pater J, Mackillop WJ (1995) Does knowledge guide practice? Another look at the management of non-small-cell lung cancer. J Clin Oncol 13: $1904-1911$

Rosell R, Gatzemeier U, Betticher DC, Keppler U, Macha HN, Pirker R, Berthet P, Breau JL, Lianes P, Nicholson M, Ardizzoni A, Chemaissani A, Bogaerts J, Gallant G (2002) Phase III randomised trial comparing paclitaxel/carboplatin with paclitaxel/cisplatin in patients with advanced non-small-cell lung cancer: a cooperative multinational trial. Ann Oncol 13: $1539-1549$

Schiller JH, Harrington D, Belani CP, Langer C, Sandler A, Krook J, Zhu J, Johnson DH, The Eastern Cooperative Oncology Group (2002) Comparison of four chemotherapy regimens for advanced non-smallcell lung cancer. $N$ Engl J Med 346: $92-98$

Shepherd FA, Dancey J, Ramlau R, Mattson K, Gralla R, O'Rourke M, Levitan N, Gressot L, Vincent M, Burkes R, Coughlin S, Kim Y, Berille J (2000) Prospective randomized trial of docetaxel $v s$ best supportive care in patients with non-small-cell lung cancer previously treated with platinum-based chemotherapy. J Clin Oncol 18: 2095-2103

Silvestri G, Pritchard R, Welch HG (1998) Preferences for chemotherapy in patients with advanced non-small cell lung cancer: descriptive study based on scripted interviews. BMJ 317: $771-775$

Sweeney CJ, Zhu J, Sandler AB, Schiller J, Belani CP, Langer C, Krook J, Harrington D, Johnson DH (2001) Outcome of patients with a performance status of 2 in Eastern Cooperative Oncology Group Study E1594. A Phase III trial in patients with metastatic nonsmall cell lung carcinoma. Cancer 92: 2639-2647

Wozniak AJ, Crowley JJ, Balcerzak SP, Weiss GR, Spiridonidis CH, Baker LH, Albain KS, Kelly K, Taylor SA, Gandara DR, Livingston RB (1998) Randomized trial comparing cisplatin with cisplatin plus vinorelbine in the treatment of advanced non-small-cell lung cancer: a Southwest Oncology Group study. J Clin Oncol 16: 2459-2465 